\title{
Metodički pristup u radu sa darovitom decom
}

\author{
Bojan Grujić \\ Škola kreativnih veština, Jagodina, Srbija \\ Momčilo Stepanović \\ OŠ „,Banović Strahinja”, Beograd, Srbija
}

\begin{abstract}
Apstrakt
Potrebe koje nameće savremena nastavna praksa su da nastavnici moraju da imaju dovoljno znanja i kompetencija o karakteristikama i potrebama darovite dece u procesu identifikacije i adekvatnog podučavanja. Da bi nastava bila razvijajuća za darovitog učenika, nastavnik mora da razume i prihvati postojanje individualnih razlika među učenicima i da prilagodi proces podučavanja i učenja različitim sposobnostima, potrebama, sklonostima, predhodnim iskustvima i znanjima, interesovanjima i stilovima učenja darovitih učenika. Sa druge strane nastavnici u pripremi i realizaciji obrazovno - vaspitnih aktivnosti, moraju da uzimaju u obzir specifičnosti razvoja darovitih učenika, ne zapostavljajući podršku ni na njihovom socio-emocionalnom nivou funkcionisanja. Učenici napreduju tako prema svojim mogućnostima, uz angažovanje svih svojih potencijala i razvoja divergentnog mišljenja. Takva nastava zadovoljava psihološke potrebe i aspiracije i pozitivno utiče na osamostaljivanje i razvoj kreativnosti. Cilj rada je analiza metodičkog pristupa nastavnika na prepoznavanju i pružanju dodatne podrške u radu sa darovitom decom/učenicima. Uzimajući sve u obzir, efikasno zadovoljavanje obrazovnih potreba darovitih učenika nameće kreiranje različitih metodičkih pristupa i strategija u radu, u kojima preovladavaju forme aktivne nastave, čiji su primarni ciljevi konstrukcija, a ne transmisija znanja. Treba razvijati aktivan odnos prema učenju i kritički odnos prema onome što se uči. Akcenat je na mentalnom razvoju učenika i praktičnoj primeni naučenog. To su oni oblici nastave koji imaju istraživački karakter, čiji je akcenat na samostalnom istraživanju, rešavanju problema i pronalaženju novih rešenja. Ciljevi takve nastave moraju da budu logičko povezivanje stečenih znanja, formiranje sistema znanja i njihova apstrakcija i primena u svakodnevnom životu. Sve to ima za posledicu racionalizaciju procesa učenja i veću efikasnost obrazovnog rada. Didaktička rešenja koja zadovoljavaju ove tendencije su individualizovana nastava sa elementima problemske i egzemplarne nastave. Mogli bismo iz ovakvih stavova zaključiti da se ishodi obrazovanja i vaspitavanja svih učenika približavaju ishodima obrazovanja i vaspitavanja darovitih.
\end{abstract}

Ključne reči: nadareno dete, obrazovne potrebe, metodološki pristup, identifikacija darovitosti, didaktička rešenja.

\section{Uvod}

Razlozi za bavljenje problematikom rada sa darovitim učenicima u okviru našeg obrazovnog sistema mogu se svesti na dva osnovna pitanja: pitanje vezano za njihovu identifikaciju i pitanje u vezi sa metodičkim pristupom u radu sa njima.

Potrebe koje nameće savremena nastavna praksa su da nastavnici moraju da imaju dovoljno znanja i kompetencija o karakteristikama i potrebama darovite dece u procesu identifikacije i adekvatnog

(C) Pripada autoru. http://creativecommons.org/licenses/by/4.0/. Korespondencija: Bojan Grujić. E-mail: skolakreativnih@gmail.com. 
podučavanja. Zadovoljenje razvojnih potreba darovitih učenika zahteva kreairanje jasnije obrazovne strategije, pri čemu bi se u prvi plan naglasio odnos društva prema darovitim učenicima kao preduslov njihovog samoostvarivanja.

Daroviti su ljudi čiji um funkcioniše tako da mogu da „vide“ dalje i dublje, koji su kadri da brže uočavaju uzročno-posledične odnose, razumeju kako šta funkcioniše i koji zahvaljujući svojim sposobnostima mogu najviše da pruže. Njihovo polazište nije samo ono što su naučili, već ono što su, u svom razvojnom procesu, sami otkrili. Karakteriše ih snažan lični stav usled kojeg često ne uživaju u razumevanju okruženja (Howes, 2000). Podrazumeva se da prednjače u onome čime se bave, ali sama darovitost nije baš tako jednostavna jer, sama po sebi ne podrazumeva ni liderstvo, ni lako uklapanje u svakodnevni žiovot.

Daroviti često imaju svoj stav koji se razlikuje od stava većine, pa i od ustaljenih normi; teže pristaju da neko drugi „misli“ umesto njih; imaju „svoj svet normi i pravila“ - teraju po svom; imaju posebnu vrstu odgovornosti i etike. Rezultat svega toga može da bude neprilagodljivost, otpor sredine, nedovoljno razumevanje (Sutherlend, 2000). To znači da se darovitost može posmatrati sa više gledišta.

Predrasuda je da je darovitost uvek „očigledna“ i uvek konstruktivna. Iza nekih od najdestruktivnijih dela stoje daroviti - oni čija je darovitost usmerena u destruktivnom smeru. Zato je važno da pomerimo granice shvatanja darovitima i potrebama darovite dece. lako je nesumnjivo da daroviti mogu najviše da pruže, to ne znači da se to i ostvaruje. Kao i ostalima i darovitima je neophodno razumevanje i podrška. Ponekad još i veća i složenija.

Upravo zato što mogu najviše da pruže, daroviti zaslužuju posebnu pažnju. U tom smislu, bitka za darovite je bitka za bolju budućnost. Ako želimo da ovaj svet iza nas ostavimo boljim nego što smo ga zatekli, onda je pitanje identifikacije onih koji mogu najviše i adekvatne podrške, veoma važno.

Daroviti se danas susreću sa različitim izazovima, od toga da budu "kovani u zvezde" pa do nerazumevanja okoline, ismevanja, podrugivanja, pa i omalovažavanja. Kada su deca u pitanju, skloni smo da verujemo da svi daroviti pažljivi na časovima, da vole da idu u školu, da uče, da uvek dobijaju dobre ocene i postižu uspeh, da su samostalni i da im nije potrebna posebna podrška. Danas daroviti koji se pozitivno izdvajaju lako dobijaju epitet "štreberi".

Okruženje često smatra da se daroviti učenici "prave važni", da se postavljaju iznad ostalih, da imaju manje emocionalnih i socijalnih problema, da su izrazito ambiciozni i da se lako prepoznaju. Takva shvatanja darovitosti možemo okarakterisati kao jednostrana i površna. Darovitost ne podrzumeva uvek konstruktivno ponašanje u skladu sa očekivanim normama ponašanja učenika. Često se dešava da nepriznata ili neprepoznata darovitost skrene na destruktivnu stranu i da umesto sjajnog učenika imamo prosečnog, a ponekad i problematičnog.

\section{Prepoznavanje i podrška darovitosti}

lako darovitost pre svega podrazumeva intelektualnu dominantnost, to ne znači da je taj kapacitet preovlađujući kada je u pitanju ostvarivanje darovitosti i uspešnost. Jedno je pitanje da li neko može da postige određeni rezultat, a drugo, da li je emocionalno i socijalno spreman da uloži potreban napor. Drugim rečima, jedna stvar su intelektualne sposobnosti, a druga njihovo korišćenje koje zavisi od emocionalnih i socijalnih sposobnosti i veština. 
Istraživanje sprovedeno među članovima Mense Srbije 2017. ${ }^{1}$ godine nedvosmisleno je potvrdilo da intelektualni kapaciteti nisu garancija uspešnosti ni u školi, a ni u životu. Ono što je posebno zanimljivo, prema navedenom istraživanju, manje od $20 \%$ ispitanika se izjasnio da je način rada u školi odgovarao njihovim potrebama, a bilo je i onih koji sebe smaraju žrtvom sistema obrazovanja, šta god da to konkretno značilo. To je još jedno ozbiljno upozorenje da nešto po pitanju identifikacije, tretmana $\mathrm{i}$ podrške darovitima treba da se menja.

Praktično posmatrano, oni koji su mogli mnogo da pruže ostali su u senci, neprepoznati, neostvareni, nezadovoljni. Neki od njih, iako se nisu snašli u školi, snašli su se u životu, ali neki se nisu snašli na nijednom bitnom životnom planu.

Darovitost nije postignuće, već potencijal koji obavezuje. Darovita osoba može i treba da uzvraća plodovima svoje posebnosti, i to ne samo na ličnom planu, već i na zajedničkom. Tek kroz produkte i ostvarenost darovitost dobija svoj puni smisao. Bez produkata ona ostaje samo neostvareni potencijal. Upravo taj momenat ukazuje na značaj blagovremene identifikacije i adekvatne podrške.

Poznato je da su intelektualne sposobnosti u značajnoj meri genetski uslovljene i da je zona njihovog razvoja time ograničena, ali moramo uzeti u obzir kristalizovanu inetigenciju koja je proizvod kulturnog i obrazovnog iskustva. Podrška darovitima pre svega podrazumeva podršku u emocionalnom i socijalnom razvoju. Možemo to nazvati i podrškom u mentalnom razvoju, koja se ostvaruje kroz razvijanje svesti o posebnosti. Ovo je važno jer saznanje o darovitosti na neki način obavezuje sve one koji rade sa decom da podrže njeno ostvarivanje.

Nažalost puno je darovitih koji nisu svesni da su daroviti, a ima i onih koji su ubeđeni u suprotno. Koliko je samo onih koji su zbog osećaja neprihvaćenosti ili nerazumevanja, ubedili sebe da su nesposobni. Takvima je podrška i motivacija za dosezanje viših ciljeva najvažnija.

Najlakša za prepoznavanje je darovitost koja se svrstava u grupu "savršenih". Osim visoke inteligencije karakteriše ih i emocionalna i socijalna stabilnost, kvalitetna motivacija, samopouzdanje i sklonost ka liderstvu. To su ona deca koja se nameću inteligencijom, ali i radom i dobrotom (Đorđević, 1995). Ona prva budu prepoznata i podržana, ako ne na drugi način, a ono bar "dobrim vetrom u leđa", odnosno da porodica prepozna i bude podsticajna sredina za razvoj darovitosti kod dece. Na drugoj strani, najosetljivija grupa darovitih je ona sa takozvanom "duplom dijagnozom".

Njih karakteriše visok nivo intelektualnih sposobnosti koji se manifestuje kao briljantnost u jednoj ili nekoliko oblasti, ali uz određeni hendikep na nekom drugom polju, najčešće na emocionalnom ili socijalnom planu. Takva deca lako dobiju negativnu etiketu "osobenjaka", "zaluđenika" ili slično, i ne samo da ne budu podržana, već često budu i sputavana. Razlog za to je njihovo otežano prilagođavanje na režim rada, pravila ponašanja ili sklonost da se bave samo onim što ih zanima, a da zanemaruju ono što im ne privlači pažnju.

lako se često smatraju "šetačima po oblacima", takva deca upravo zbog svoje snažne posvećenosti, najčešće pomeraju granice u svojim oblastima. Njima je najpotrebnije da bude prepoznato o čemu se zapravo radi, i da im se pruži adekvatna podrška. lako se najteže uklapaju, na duže staze posmatrano, u svojim oblastima pružaju najviše i ostvaruju najveće domete.

Praksa poznaje različite procedure za identifikaciju i verifikaciju darovitosti, ali nekako najvažniji korak u današnjim uslovima je ipak standardizovana (testovna) procena na osnovu koje se vrši "nominacija". Čak i da se neko dete koje je samo talentovano, a nije darovito, tretira kao darovito, od

${ }^{1}$ Prva međunarodna Mensina konferencija „Darovitost prepoznavanje i podrška“, Novi Sad ( 2017 ). 
toga neće biti štete. Na drugoj strani, velika je šteta kada darovito dete ne dobije priliku da osvesti svoju posebnost, a posebno kada se darovitost ,guši".

U školskim uslovima za darovite se najčešće nominuju deca koja se ističu radom ili uspesima na takmičenjima. Postignuća po osnovu posvećenosti i zalaganja su jedno, a postignuća po osnovu darovitosti nešto drugo. Prva se zasniva na emocionalnim i mentalnim kapacitetima, a druga na intelektualnim. Prvi postižu dobre rezultate zato što puno rade i time stiču iskustvo, a drugi time što razmišljaju brže i bolje uočavaju veze među raspoloživim podacima.

Vrhunski rezultati dolaze kada su oba ta kvaliteta ujedinjena u jednoj ličnosti. Nema te darovitosti koja će se u značajnijoj meri ostvariti bez rada i posvećenosti. Zato je od ključne važnosti pokretanje darovitih da rade, razvijaju radne navike, emocionalne i socijalne kapacitete (Stojković, 2000). Ako nemaju radne navike, utapaju se u prosečnost i zadovoljavaju postignućima baziranim na sposobnostima.

Put podrške darovitima u školi može da bude formalan i neformalan. Formalan podrazumeva da se darovitost dokaže validnim instrumentima i da se zatim izvrši individualizacija zahteva. Zakon propisuje takvu proceduru, ali se često u nastavnoj praksi darovitost zanemaruje. Pošto procedura podrazumeva niz administrativnih aktivnosti i obaveza, koje uz to ne zavise samo od samog nastavnika, većina nastavnika se opredeljuje za takozvanu neformalnu podršku kroz sekcije i takmičenja. I takav vid podrške je dragocen, naravno ako se sprovodi na dobar način koji podrazumeva da je u prvom planu razvoj dobar razvoj ličnosti učenika, a ne sami rezultati koji se ponekad umesto učeniku pripisuju nastavniku.

Optimalni vid podrške darovitim učenicima je IOP-3, procedura zahvaljujući kojoj je moguće obogaćivanje programa nastavnim sadržajima, a i drugi vidovi stimulacije. Pretpostavlja se da je broj IOP3 značajno manji u odnosu na IOP-1 i IOP-2 kojima se vrši podrška deci sa teškoćama u učenju i razvoju. lako zvanični podaci o tome ne postoje, vlada opšte mišljenje da je broj dece sa teškoćama u razvoju i darovitih približno isti.

U metodološkom smislu osmišljavanje plana podrške rada sa darovitim učenicima formalno je isti kao i plan podrške rada sa učenicima koji imaju poteškoće u učenju i razvoju. Da bi nastava podsticala razvoj u prvom slučaju podižemo nivo aspiracije obogaćivanjem sadržaja nastave mogućnostima darovitih, dok u drugom slučaju spuštamo nivo aspiracije i očekivanja kako bi sadržaji nastave odgovarali potrebama učenika sa poteškoćama. I u prvom i u drugom slučaju nastava mora da bude razvijajuća. Postavljamo onda pitanje, zašto je u našoj nastavnoj praksi po školama mnogo više IOP-a 2 nego IOP-a 3. Odgovore treba tražiti pre svega u manjkavosti tradicionalne nastave, koja je pre svega usmerena na realizaciju glomaznih planova i programa, koji u najvećoj meri sputavaju rad sa darovitim učenicima. Takva nastava teži ishodima koji počivaju na već gotovim i enciklopedijskim znanjima, koja ne odgovaraju potrebama darovitih (Gojkov, 2008). Daroviti učenici imaju potrebu za slobodom u mišljenju, nekonformizmom u ponašanju, nezavisnosti u delovanju, originalnošću u stvaralačkom ispoljavanju, da diskutuju i raspravljaju, da budu shvaćeni i prihvaćeni. Što se tiče samog rada u učionici, nastavnik mora da obezbedi atmosferu u kojoj se kreativno mišljenje aktivno ohrabruje, gde se podržava i neguje spontanost, razigranost, radoznalost, traganje za novim izazovima i odgovorima, otvorenost za novo i drugačije, gde se stvara emocionalna sigurnost i odsustvo straha od neuspeha.

Novija istraživanja ukazuju da je najvažniji uticaj porodice i nastavnika u radu sa darovitim učenicima u oblasti socio-emocijalnog razvoja (Blum, 1985). Taj uticaj se pre svega ogleda u otklanjanju poremećaja u ponašanju, boljeg prihvatanja sebe i sopstvenih potreba, bolje adaptacije na socijalno 
okruženje. Ako nastavnik prihvati dete onakvo kakvo jeste, onda će ga i druga deca i učenici prihvatiti onakvo kakvo jeste.

Sa druge strane sposobnosti rešavanja socio-emocionalnih i kognitivnih problema biće mnogo veća ukoliko se učenik oseti dobro prihvaćenim i prilagođenim na nivou svoje vršnjačke grupe. Nerealno visoka očekivanja takođe mogu da proizvedu suprotan efekat. Ukoliko su zahtevi suviše visoko postavljeni, učenik trpi pritisak i ne postiže ni ono što realno može i ume. Postavljanje realnih očekivanja od strane porodice i nastavnika, osnovni je preduslov za optimalan razvoj ličnosti darovite dece.

\section{Zaključak}

Imati darovito dete u odeljenju predstavlja pravi izazov za svakog nastavnika. Darovita deca uče brže od vršnjaka, kreativni su i tvrdoglavi i često se teško prilagođavaju društvenim konvencijama. Daroviti učenici jasnije uočavaju nekompetentnost nastavnika. Ponekad nastavnici nemaju razumevanja za darovitu decu koju doživljavaju kao prezahtevnu ili napornu u svakodnevnom radu. Takva deca mogu biti "naporna" jer imaju mnogo pitanja, pamte sve odgovore i na temelju njih postavljaju nova pitanja. Iz navedenih razloga, ponekad darovito dete može biti okarakterisano kao neposlušno jer ima svoje stavove.

Program rada sa nadarenom decom, uključuje pre svega identifikovanje potencijalno darovitog deteta, utvrđivanje njegovih mogućnosti, potreba i interesa te uvažavanje specifičnih interesa i produbljivanje istih. Takođe, uključuje omogućavanje detetu da nauči sve što ga zanima, na način na koji mu odgovara i pritom mu za te aktivnosti pružiti dovoljno vremena. Takvoj deci svakako treba organizovati složenije aktivnosti, naročito u pogledu angažovanja apstraktnog i stvaralačkog mišljenja.

U našem obrazovnom sistemu briga o darovitoj deci je prisutna kroz postojanje različitih, parcijalnih rešenja, ali bez sveobuhvatnog pristupa u radu sa decom i učenicima sa posebnim sposobnostima, koji bi obuhvatio identifikovanje, školovanje, podsticanje i praćenje razvoja i postignuća.

Uzimajućiu obzir, efikasno zadovoljavanje obrazovnih potreba darovitih učenika nameće kreiranje različitih metodičkih pristupa i strategija u radu, u kojima preovladavaju forme aktivne nastave, čiji su primarni ciljevi konstrukcija a ne transmisija znanja. Treba razvijati aktivan odnos prema učenju i kritički odnos prema onome što se uči. Akcenat je na mentalnom razvoju učenika i praktičnoj primeni naučenog. To su oni oblici nastave koji imaju istraživački karakter, čiji je akcenat na samostalnom istraživanju, rešavanju problema i pronalaženju novih rešenja.

Ciljevi takve nastave moraju da budu logičko povezivanje stečenih znanja, formiranje sistema znanja i njihova apstrakcija i primena u svakodnevnom životu. Sve to ima za posledicu racionalizaciju procesa učenja i veću efikasnost obrazovnog rada.

Didaktička rešenja koja zadovoljavaju ove tendencije su individualizacija i diferencijacija sa elementima heruističke, problemske i egzemplarne nastave. Primenom odgovarajućih nastavnih rešenja i postupaka, mogu se na adekvatan način zadovoljiti potrebe, mogućnosti i interesovanja darovitih učenika. Ovakva nastava i razrađene metode omogućuju veću unutrašnju motivaciju kod učenika za razvoj kreativnih potencijala ličnosti. Savremena nastavna praksa, zahteva od nastavnika osmišljavanje kombinacije atraktivnijih metodičkih modela koji će nastavu učiniti zanimljivijom i funkcionalnijom za razvoj darovitih učenika. Sa druge strane važno je da nastavnici stvore okruženje za učenje koje će biti podsticajno za napredovanje darovite dece. Mogli bismo iz ovakvih stavova zaključiti da bi trebalo da se ishodi obrazovanja i vaspitavanja svih učenika, približavaju ishodima obrazovanja i vaspitavanja darovitih. 
Sistematska briga o darovitima je strateško pitanje za svaku zemlju, a posebno za našu koja zbog znatnog zaostajanja treba pronaći mogućnosti za ubrzan razvoj. Naime, treba imati u vidu da se ekonomske pozicije sve više ostvaruju u sferi intelektualnihpostignuća. Stoga bi jedna od ključnih strategija za postizanje međunarodne konkurentnosti Srbije trebalo biti upravo ulaganje u darovite i kreativne pojedince.

Uz postojeća, vrlo ograničena sredstva najveći mogući efekti mogu se ostvariti kroz unapređivanje identifikacije $\mathrm{i}$ metodičke podrške darovitim učenicima koji su naš najvredniji $\mathrm{i}$ nedopustivo zanemaren potencijal.

\section{Korišćena literatura}

Bloom, B. (1985). Developing talent in young people. New York: Ballantine Books

Đorđević, B. (1995). Daroviti učenici i (ne)uspeh. Beograd: Zajednica učiteljskih fakulteta Srbije.

Gojkov, G. (2008). Didaktika darovitih. Vršac: Visoka škola strukovnih studija za obrazovanje vaspitača „Mihailo Pavlov".

Howes, C. (2000). Social - emotional climate in child care, child - teacher relationships and children's second grade peer relations. Social Developmet, 9(2), 191-204.

Maksić, S. (1998). Darovito dete u školi. Beograd: Institut za pedagoška istraživanja.

Stojković, P. (2000). Darovitost i kreativnost (savremeni modeli podsticanja i razvoja darovitosti i kreativnosti). Srpsko Sarajevo: Zavod za udžbenike i nastavna sredstva Republike Srpske.

Sutherland, K.S. (2000). Promoting positive interactions between teachers and students with emotional/behavioral disorders. Preventing School Failure, 44(3), 110-115. 


\title{
Methodological Approach in Working With Gifted Children
}

\author{
Bojan Grujić \\ Škola kreativnih veština, Jagodina, Serbia \\ Momčilo Stepanović \\ OŠ „,Banović Strahinja”, Belgrade, Serbia
}

\begin{abstract}
The needs imposed by modern teaching practice are that teachers must have sufficient knowledge and competence about the characteristics and needs of gifted children in the process of identification and adequate teaching. In order for the teaching to be evolving for a gifted student, the teacher must understand and accept the existence of individual differences among students and to adapt the process of teaching and learning to different abilities, needs, preferences, past experiences and knowledge, interests and learning styles of gifted students. On the other hand, teachers in the preparation and realization of educational and educational activities must take into account the specificity of the development of gifted pupils, without neglecting support at their socio - emotional level of functioning. Students are progressing according to their abilities, with the engagement of all their potentials and the development of divergent thinking. Such teaching meets psychological needs and aspirations and positively influences the self-esteem and development of creativity. Taking into consideration the fact that the effective fulfillment of the educational needs of gifted students imposes the creation of different methodical approaches and strategies in the work, in which the forms of active teaching dominate, whose primary goals are constructions, not knowledge transmissions. An active attitude towards learning and a critical attitude towards what is being taught should be developed. The emphasis is on the mental development of students and the practical application of the learned. These are forms of teaching that have a research character, whose emphasis is on independent research, problem solving and finding new solutions. Didactic solutions that satisfy these tendencies are individualized classes with elements of problematic and exemplary teaching. We could conclude from these attitudes that the outcomes of education and upbringing of all students are approaching the outcomes of education and upbringing of the gifted.
\end{abstract}

Key words: gifted children, educational needs, methodological approach, identification of giftedness, didactic solutions. 
B. Grujić i M. Stepanović - Metodički pristup u radu sa darovitom decom

$$
* * * * *
$$

